\title{
TRYPANOSOMA CRUZI DNA IN CARDIAC LESIONS OF ARGENTINEAN PATIENTS WITH END-STAGE CHRONIC CHAGAS HEART DISEASE
}

\author{
ALEJANDRO G. SCHIJMAN, CARLOS A. VIGLIANO, RODOLFO J VIOTTI, JUAN M. BURGOS, SILVIA BRANDARIZ, \\ BRUNO E. LOCOCO, MARIA I. LEZE, HECTOR A. ARMENTI, AND MARIANO J. LEVIN \\ Laboratorio de Biología Molecular de la Enfermedad de Chagas, INGEBI, Consejo Nacional de Ciencia y Tecnologia, Department \\ of Fisiology, Celular and Molecular Biology, F.CEyN, University of Buenos Aires, Buenos Aires, Argentina; Department of \\ Cardiology, Eva Perón Hospital, San Martin, Buenos Aires, Argentina; Division of Pathology, Instituto de Cardiología y Cirugía \\ Cardiovascular, Fundación Favaloro, Buenos Aires, Argentina
}

\begin{abstract}
The extent of inflammation, fibrosis, and progression of chronic Chagas heart disease (cChHD) was associated with persistence of parasite DNA in cardiac lesions of necropsies or explants from Argentinean cChHD patients. A Trypanosoma cruzi-based polymerase chain reaction showed a positive result in 1) $15 \%$ of cardiac sections with less than 10 mononuclear inflammatory cells/high-power field (440×) (MNC/HPF), 89\% with 10-19 MNC/HPF, and $100 \%$ with more than $20 \mathrm{MNC} / \mathrm{HPF}(P<0.0001)$; 2$) 33 \%$ with less than $10 \%$ fibrosis, $79 \%$ with $10-19 \%$ fibrosis, and $100 \%$ with more than $20 \%$ fibrosis $(P<0.01) ; 3) 25 \%$ of specimens from patients classified in Kuschnir groups 0 and I, $70 \%$ in group II and $90 \%$ in group III $(P<.001)$; and 4$) 45 \%$ and $90 \%$ of the specimens from cChHD patients without or with heart failure, respectively $(P<0.01)$. These findings stress the role of the parasite in pathogenesis and disease progression of cChHD.
\end{abstract}

\section{INTRODUCTION}

Chagas disease is the main cause of chronic myocarditis in Latin American countries, where the disease is endemic, affecting approximately 20 million people. ${ }^{1}$ Fifty thousand chagasic patients die every year, mainly due to a chronic cardiomyopathy that is clinically evident only $10-30$ years after the initial infection. ${ }^{2}$

Chronic Chagas heart disease (cChHD) evolves gradually from an asymptomatic period with radiographic or electrocardiographic manifestations known as the indeterminate phase, and progresses slowly to a dilated cardiomyopathy manifested by arrhythmias, left ventricular dysfunction, embolic episodes, and autonomic dysfunction. ${ }^{2,3}$ The apical aneurysm is found to be a distinctive pathologic marker in more than $50 \%$ of symptomatic patients. ${ }^{4}$

In general, the cause of death is heart failure or thromboembolic phenomena. Anatomically, the heart of a patient with cChHD is characterized by myocardial damage associated with mononuclear inflammatory foci scattered throughout the organ. ${ }^{2,4}$ The coexistence of areas of myocytic degeneration, inflammatory infiltration, and fibrosis suggests a chronically evolving process. The lesions are progressive, selfperpetuating, and cumulative.

Since the intracellular forms of the parasite (Trypanosoma cruzi) that cause this disease are rarely found at the sites of the heart lesions, the hypothesis of an autoimmune process has been proposed as a leading mechanism of cChHD pathogenesis. ${ }^{5,6}$ However, polymerase chain reaction (PCR) amplification and immunohistochemical techniques showed the presence of parasite DNA and proteins close to the inflammatory foci in lesions found in cardiac and digestive tissue from patients infected in endemic areas in Brazil and Venezuela. $^{6-11}$

In this study, we applied the PCR technique to analyze the proportion of sections containing parasite DNA in left ventricular free walls or cardiac apexes collected from heart necropsies or explants in cChHD patients from Argentina who died at different stages of heart disease progression. The combination of clinical, electrocardiographic, histologic and PCR-based analysis enabled us to demonstrate a significant association between the detection of parasite DNA with inflammation, fibrosis, and clinical progression of cChHD.

\section{MATERIALS AND METHODS}

Study groups. Hearts from three groups of patients collected at necropsy and from transplant recipients were studied. Group A included hearts from six cChHD patients without symptoms of heart failure (HF). Group B included hearts from 10 patients with severe cChHD (New York Heart Association functional classes III and IV) who had died or were treated with heart transplants. Group C (control group) included hearts from six patients with non-chagasic cardiomyopathy (DCM) with HF (New York Heart Association functional classes III and IV) at the time of death or heart transplantation. Chronic ChHD and DCM patients were followedup by the Service of Chagas Disease of the Department of Cardiology, Hospital Eva Perón (San Martín, Buenos Aires, Argentina). The patients had undergone heart transplantation at the Instituto de Cardiología y Cirugía Cardiovascular, Fundación Favaloro in Buenos Aires. The diagnosis of Chagas disease relied on positive results in at least two of three conventional serologic assays: complement fixation, indirect hemagglutination, and indirect immunofluorescence. This study was reviewed and approved by the Biomedical Ethics Committee of the Instituto de Cardiología y Cirugía Cardiovascular de la Fundación Favaloro and that of the Eva Perón Hospital. Patients undergoing heart transplants gave informed consent to have their explanted hearts analyzed. The other heart specimens included in the study were obtained from necropsy specimens that were retrospectively analyzed.

On admission, cChHD patients were clinically classified according to the criteria of Kuschnir into four groups: 0 (positive serology only), I (abnormal electrocardiogram [ECG], II (radiologic heart enlargement), and III (overt signs of heart failure). ${ }^{12}$ At the time of death or heart transplantation the patients were reclassified based on the progression of the cardiomyopathy. Such progression was determined according to 1) development of new electrocardiographic changes (NEC): right bundle branch block (RBBB), left anterior fascicular block (LAFB), RBBB plus LAFB, left bundle branch 
block (LBBB), complete atrial ventricular block (CAVB), atrial fibrillation (AF), atrial flutter (AA), atrial tachycardia, and sustained ventricular tachycardia (SVT); and 2) deterioration of the clinical group.

The cChHD patients included in this study did not receive trypanocidal therapy. Patients undergoing heart transplantation did not receive trypanocidal prophylaxis. Their clinical and ECG conditions are shown in Table 1.

Collection of histologic heart sections. Transmural sections at the apex, atrium and the whole circumference of the third cut were collected in all hearts, according to the procedures of Edwards and others. ${ }^{13}$ Samples were fixed in $10 \%$ buffered formaldehyde and embedded in paraffin. After evaluation of all histologic heart tissue sections, we selected two from each heart, one with the lowest degree of inflammation (section a, Table 2) and the other one with the highest degree (section b,
Table 2). From each selected histologic section, a $5 \mu \mathrm{m}$-thick slice was stained with hematoxylin and eosin and Masson's trichrome. Twenty high-power fields (HPFs) were examined at $400 \times$ magnification: five of the subepicardial myocardium, five of the outer mesocardium, five of the inner mesocardium, and five of the subendocardium.

The number of mononuclear cells (MNC) and the percentage of fibrosis were determined on each HPF using an eye piece mounted grid with a surface of $0.05 \mathrm{~mm}^{2}$. The degree of myocarditis was defined for each heart according to the Dallas criteria. ${ }^{14}$ For statistical purposes, sections were classified in three groups, those with low inflammation and less than 10 $\mathrm{MNC} / \mathrm{HPF}$, those with moderate inflammation and between 10 and $19 \mathrm{MNC} / \mathrm{HPF}$, and those with high inflammation with at least $20 \mathrm{MNC} / \mathrm{HPF}$. The percentage of fibrosis was calculated following the grading system of Kunkel and others. ${ }^{15}$

TABLE 1

Clinical data of patients with chronic Chagas disease and dilated cardiomyopathy*

\begin{tabular}{|c|c|c|c|c|c|c|c|c|c|c|c|}
\hline \multirow[b]{2}{*}{ Group } & \multirow[b]{2}{*}{ Patient } & \multirow[b]{2}{*}{$\begin{array}{c}\text { Age } \\
\text { (years) }\end{array}$} & \multirow[b]{2}{*}{ Sex } & & \multicolumn{6}{|c|}{ Clinical outcome } \\
\hline & & & & $\begin{array}{l}\text { Admission } \\
\text { ECG }\end{array}$ & CGA & NEC & $\underset{(\mathrm{mm})}{\mathrm{LVDD}}$ & $\underset{\text { (months) }}{\mathrm{HF}}$ & $\begin{array}{c}\mathrm{TF} \\
\text { (days) }\end{array}$ & FCG & $\begin{array}{l}\text { Cause of death or heart } \\
\text { transplantation }\end{array}$ \\
\hline \multirow[t]{6}{*}{$\mathrm{A}$} & 1 & 55 & $\mathrm{M}$ & Normal & 0 & No & ND (CTR 0,49) & No & 3 & 0 & Intracerebral hemorrhage \\
\hline & 2 & 52 & $\mathrm{M}$ & Normal & 0 & No & ND (CTR 0,50) & No & 13 & 0 & $\begin{array}{l}\text { PO (chagasic megacolon) } \\
\text { sepsis }\end{array}$ \\
\hline & 3 & 65 & $\mathrm{~F}$ & $\begin{array}{l}\text { RBBB VPC Lown } 4 \\
\text { SVE }\end{array}$ & I & LAHB & 52 & No & 1,401 & I & $\begin{array}{l}\text { PO (carcinoma of the ex- } \\
\text { trahepatic bile ducts) }\end{array}$ \\
\hline & 4 & 46 & $\mathrm{M}$ & $\begin{array}{l}\text { RBBB CAVB LAE } \\
\text { RVH }\end{array}$ & II & PP & ND (CTR 0,54) & No & 1,434 & II & PO (renal cell carcinoma) \\
\hline & 5 & 40 & $\mathrm{~F}$ & $\begin{array}{l}\text { LAHB T wave } \\
\text { changes VPC } \\
\text { Lown } 2\end{array}$ & II & No & 66 & No & 2,298 & II & Eclampsia \\
\hline & 6 & 71 & $\mathrm{M}$ & RBBB LAHB & II & No & ND (CTR 0,57) & No & 36 & II & $\begin{array}{l}\text { Cardiac arrest during anes- } \\
\text { thesia induction (benign } \\
\text { prostatic hyperplasia) }\end{array}$ \\
\hline \multirow[t]{10}{*}{$\mathrm{B}$} & 7 & 48 & $\mathrm{M}$ & $\begin{array}{l}\text { RBBB LAHB VPC } \\
\text { Lown } 2\end{array}$ & I & VT VF PP & 63 & 13 & 3,000 & III & Sudden cardiac death \\
\hline & 8 & 79 & $\mathrm{~F}$ & $\begin{array}{l}\text { VPC Lown } 3 \text { LAE T } \\
\text { wave changes }\end{array}$ & II & $\mathrm{AF}$ & 72 & 15 & 1,770 & III & Pulmonary embolism \\
\hline & 9 & 54 & $\mathrm{~F}$ & $\begin{array}{l}\text { SB AVB1 } 1^{\circ} \text { VPC T } \\
\text { wave changes VT }\end{array}$ & II & PP & 65 & 1 & 1,771 & III & HF \\
\hline & 10 & 41 & $\mathrm{~F}$ & $\begin{array}{l}\mathrm{AVB}^{\circ} \mathrm{RBBB} \\
\mathrm{LAHB}^{-}\end{array}$ & III & CAVB VT VF & 74 & 24 & 63 & III & $\mathrm{HF} /$ acute pancreatitis \\
\hline & 11 & 58 & $\mathrm{M}$ & $\begin{array}{l}\text { EIA (lateral) RAE } \\
\text { LAE RVH }\end{array}$ & III & AF VT & 91 & 21 & 414 & III & $\mathrm{HF}$ \\
\hline & 12 & 43 & $\mathrm{M}$ & $\begin{array}{l}\text { EIA (anterior) VPC } \\
\text { Lown } 2 \text { SVE }\end{array}$ & III & VT & 78 & 10 & 289 & III & $\mathrm{HF}$ \\
\hline & 13 & 65 & $\mathrm{~F}$ & $\begin{array}{l}\text { SB }\left(40 x^{\prime}\right) \text { RBBB } \\
\text { LAHB }\end{array}$ & III & PP & 67 & 25 & 759 & III & $\mathrm{HF}$ \\
\hline & 14 & 27 & $\mathrm{M}$ & $\begin{array}{l}\mathrm{AVB}^{\circ} \text { LAHB EIA } \\
\text { (anterior) }\end{array}$ & III & RBBB CAVB & 76 & 14 & 414 & III & HF \\
\hline & 15 & 43 & $\mathrm{M}$ & $\mathrm{VT}$ & III & PP & 69 & 36 & 819 & III & $\mathrm{HF} /$ heart transplantation \\
\hline & 16 & 48 & $\mathrm{~F}$ & $\begin{array}{l}\text { RBBB LAHB VPC } \\
\text { Lown } 3 \text { SSS }\end{array}$ & III & AF VT VF PP & 72 & 19 & 387 & III & $\mathrm{HF} /$ heart transplantation \\
\hline \multirow[t]{6}{*}{$\mathrm{C}$} & A & 49 & $\mathrm{M}$ & LIBB AF & - & No & 80 & 36 & 890 & - & HF \\
\hline & B & 61 & $\mathrm{M}$ & $\begin{array}{l}\text { LBBB LVH LAE } \\
\text { RVH }\end{array}$ & - & No & 75 & 18 & 489 & - & $\mathrm{HF}$ \\
\hline & $\mathrm{C}$ & 63 & $\mathrm{~F}$ & AF LBBB & - & No & 78 & 53 & 542 & - & $\mathrm{HF} /$ heart transplantation \\
\hline & $\mathrm{D}$ & 41 & $\mathrm{M}$ & $\begin{array}{l}\text { LVH RAE LAE } \\
\text { EIA (inferior) }\end{array}$ & - & $\mathrm{AF}$ & 60 & 16 & 56 & - & $\mathrm{HF}$ \\
\hline & $\mathrm{E}$ & 45 & $\mathrm{M}$ & $\begin{array}{l}\text { LBBB LVH RAE } \\
\text { LAE }\end{array}$ & - & No & 89 & 28 & 519 & - & $\mathrm{HF} /$ heart transplantation \\
\hline & $\mathrm{F}$ & 26 & $\mathrm{~F}$ & $\begin{array}{l}\text { LAHB VPC Lown } 2 \\
\text { RAE LAE }\end{array}$ & - & No & 80 & 3 & 64 & - & $\mathrm{HF} /$ heart transplantation \\
\hline
\end{tabular}

* ECG = electrocardiogram; CGA = chagasic clinical group at admission according to Kuschnir classification ${ }^{9}$; NEC = new electrocardiographic changes; LVDD = left ventricular diastolic diameter; $\mathrm{HF}=$ heart failure; TF $=$ time of follow-up; FCG $=$ final chagasic clinical group; $\mathrm{ND}=$ not done; $\mathrm{CTR}=$ cardiothoracic ratio; $\mathrm{PO}=$ postoperative; $\mathrm{RBBB}=$ right bundle branch block; VPC $=$ ventricular premature contractions; SVE $=$ supraventricular extrasystolia; LAHB $=$ left anterior hemiblock; CAVB = complete atrioventricular block; LAE = left auricular enlargement; $\mathrm{RVH}=$ right ventricular hypertrophy; $\mathrm{PP}=$ permanent pacemaker; $\mathrm{VT}=$ ventricular tachycardia; $\mathrm{VF}=\mathrm{ventricular}$ fibrillation; $\mathrm{AF}=$ atrial fibrillation; $\mathrm{SB}=$ sinus bradycardia; $\mathrm{AVB}^{\circ}=$ first degree atrioventricular block; EIA = electric inactivation area; SSS = sick sinus syndrome; LBBB = left bundle branch block; LVH $=$ left ventricular hypertrophy; RAE = right auricular enlargement. 
TABLE 2

Pathologic and Trypanosoma cruzi (T.c.) DNA findings in autopsied or explanted hearts in CChD and DCM patients*

\begin{tabular}{|c|c|c|c|c|c|c|c|c|c|c|c|c|c|c|}
\hline \multirow[b]{2}{*}{ Group } & \multirow[b]{2}{*}{ Patients } & \multirow[b]{2}{*}{$\underset{\text { (Kuschnir) }}{\text { FCG }^{9}}$} & \multirow[b]{2}{*}{$\begin{array}{l}\text { Heart } \\
\text { weight } \\
\text { (g) }\end{array}$} & \multirow[b]{2}{*}{$\begin{array}{l}\text { Myocarditis } \\
\text { (Dallas) }^{11}\end{array}$} & \multirow[b]{2}{*}{$\begin{array}{l}\text { Fibrosis } \\
\text { (Kunkel) }^{12}\end{array}$} & \multirow{2}{*}{\multicolumn{2}{|c|}{$\begin{array}{c}\text { Histologic } \\
\text { sections } \\
20 \mathrm{HPFs}(400 \times)\end{array}$}} & \multicolumn{2}{|c|}{$\begin{array}{l}\text { Inflammation } \\
(\mathrm{MNC/HPF})\end{array}$} & \multicolumn{2}{|c|}{ Fibrosis (\%) } & \multicolumn{3}{|c|}{$\begin{array}{c}\text { Polymerase } \\
\text { chain reaction }\end{array}$} \\
\hline & & & & & & & & Median & $(25-75 p)$ & Median & $(25-75 p)$ & $\begin{array}{c}\text { Human } \\
\beta \text {-globin }\end{array}$ & $\begin{array}{c}\text { T.c. } \\
\text { kdna }\end{array}$ & Score \\
\hline \multirow{12}{*}{$\begin{array}{l}\text { A } \\
\text { (CChD without } \mathrm{HF})\end{array}$} & 1 & 0 & 310 & No & Normal & $\mathrm{a}$ & LV & 5 & $(4-6)$ & 3 & $(2-4)$ & $2 / 4$ & $0 / 2$ & 0 \\
\hline & & & & & & b & Apex & 8 & $(5-10)$ & 2 & (1-3) & $2 / 4$ & $0 / 2$ & 0 \\
\hline & 2 & 0 & 325 & Borderline & Normal & $\mathrm{a}$ & Apex & 5 & $(4-5)$ & 3 & $(2-5)$ & $2 / 4$ & $0 / 2$ & 0 \\
\hline & & & & & & b & LV & 11 & $(8-13)$ & 6 & (4-9) & $2 / 4$ & $2 / 2$ & 1 \\
\hline & 3 & I & 320 & Active & Moderate & $\mathrm{a}$ & LV & 9 & $(7-13)$ & 12 & $(9-21)$ & $2 / 5$ & $0 / 2$ & 0 \\
\hline & & & & & & b & LV & 22 & $(12-40)$ & 18 & $(11-27)$ & $2 / 5$ & $1 / 2$ & 1 \\
\hline & 4 & II & 600 & Borderline & Moderate & a & LV & 9 & $(6-10)$ & 11 & $(7-33)$ & $2 / 4$ & $0 / 2$ & 0 \\
\hline & & & & & & b & LV & 11 & $(9-13)$ & 18 & $(9-33)$ & $2 / 3$ & $2 / 2$ & 1 \\
\hline & 5 & II & 550 & Active & Moderate & a & RA & 10 & $(8-15)$ & 10 & $(6-19)$ & $2 / 2$ & $1 / 2$ & 1 \\
\hline & & & & & & b & LV & 11 & $(8-22)$ & 13 & $(10-19)$ & $2 / 2$ & $2 / 2$ & 1 \\
\hline & 6 & II & 700 & Active & Severe & b & LV & 16 & $(11-40)$ & 19 & $(12-36)$ & $2 / 3$ & $2 / 2$ & 1 \\
\hline & & & & & & $\mathrm{a}$ & $\mathrm{RV}$ & 10 & $(8-12)$ & 30 & $(19-35)$ & $0 / 5$ & ND & ND \\
\hline \multirow{20}{*}{$\begin{array}{l}\text { B } \\
\text { (CChD with HF) }\end{array}$} & 7 & III & 660 & Active & Severe & a & Apex & 19 & $(13-28)$ & 28 & $(22-52)$ & $3 / 3$ & $3 / 3$ & 1 \\
\hline & & & & & & b & LV & 28 & $(19-60)$ & 42 & $(33-54)$ & $3 / 3$ & $3 / 3$ & 1 \\
\hline & 8 & III & 380 & Borderline & Severe & a & RV & 5 & $(4-7)$ & 14 & $(4-18)$ & $0 / 5$ & ND & ND \\
\hline & & & & & & b & LV & 8 & $(5-15)$ & 30 & $(23-36)$ & $2 / 3$ & $2 / 2$ & 1 \\
\hline & 9 & III & 430 & Active & Severe & a & LV & 57 & (19-98) & 21 & $(15-26)$ & $3 / 5$ & $3 / 3$ & 1 \\
\hline & & & & & & b & LV & 81 & $(23-150)$ & 19 & $(12-25)$ & $2 / 4$ & $2 / 2$ & 1 \\
\hline & 10 & III & 380 & Active & Moderate & $\mathrm{a}$ & RV & 4 & $(3-6)$ & 11 & $(6-16)$ & $2 / 3$ & $0 / 2$ & 0 \\
\hline & & & & & & b & LV & 27 & $(6-68)$ & 15 & $(9-31)$ & $3 / 3$ & $3 / 3$ & 1 \\
\hline & 11 & III & 660 & Active & Severe & a & LV & 10 & $(8-18)$ & 28 & $(20-39)$ & $3 / 3$ & $3 / 3$ & 1 \\
\hline & & & & & & b & VS & 27 & $(16-83)$ & 32 & $(24-40)$ & $3 / 3$ & $3 / 3$ & 1 \\
\hline & 12 & III & 625 & Active & Moderate & $\mathrm{a}$ & LV & 17 & $(7-52)$ & 14 & $(10-33)$ & $2 / 4$ & $2 / 2$ & 1 \\
\hline & & & & & & b & LA & 26 & $(17-47)$ & 13 & $(8-18)$ & $2 / 5$ & $2 / 2$ & 1 \\
\hline & 13 & III & 500 & Active & Moderate & $\mathrm{a}$ & RV & 33 & $(13-55)$ & 14 & $(8-22)$ & $1 / 3$ & $1 / 1$ & 1 \\
\hline & & & & & & b & LV & 34 & $(16-60)$ & 13 & $(11-24)$ & $2 / 3$ & $1 / 2$ & 1 \\
\hline & 14 & III & 450 & Active & Severe & $\mathrm{a}$ & LV & 31 & $(23-65)$ & 29 & $(19-41)$ & $4 / 4$ & $4 / 4$ & 1 \\
\hline & & & & & & b & LV & 38 & $(29-88)$ & 31 & $(24-39)$ & $4 / 4$ & $4 / 4$ & 1 \\
\hline & 15 & III & 400 & Active & Severe & $\mathrm{a}$ & Apex & 20 & $(12-35)$ & 23 & $(20-33)$ & $2 / 2$ & $2 / 2$ & 1 \\
\hline & & & & & & b & LV & 53 & $(29-94)$ & 22 & $(17-25)$ & $2 / 2$ & $2 / 2$ & 1 \\
\hline & 16 & III & 420 & Active & Moderate & $\mathrm{a}$ & LA & 11 & $(8-14)$ & 9 & $(6-12)$ & $2 / 2$ & $0 / 2$ & 0 \\
\hline & & & & & & b & LV & 62 & $(30-95)$ & 15 & $(9-20)$ & $3 / 3$ & $3 / 3$ & 1 \\
\hline $\mathrm{C}$ & A & - & 875 & No & Mild & & LV & 7 & $(5-9)$ & 9 & $(6-12)$ & $2 / 2$ & $0 / 2$ & 0 \\
\hline \multirow{5}{*}{ (DCM with HF) } & B & - & 550 & No & Moderate & & LV & 5 & (3-7) & 16 & $(10-20)$ & $2 / 3$ & $0 / 2$ & 0 \\
\hline & C & - & 480 & Borderline & Mild & & LV & 11 & $(8-15)$ & 7 & $(5-11)$ & $2 / 2$ & $0 / 2$ & 0 \\
\hline & $\mathrm{D}$ & - & 550 & No & Mild & & LV & 7 & $(4-12)$ & 10 & $(7-19)$ & $2 / 4$ & $0 / 2$ & 0 \\
\hline & $\mathrm{E}$ & - & 755 & Borderline & Moderate & & LV & 14 & $(10-17)$ & 11 & $(6-14)$ & $2 / 2$ & $0 / 2$ & 0 \\
\hline & F & - & 315 & No & Moderate & & LV & 6 & $(4-11)$ & 12 & $(6-18)$ & $2 / 2$ & $0 / 2$ & 0 \\
\hline
\end{tabular}

$* \mathrm{CChD}=$ chronic Chagas disease; $\mathrm{DCM}=$ dilated cardiomyopathy; $\mathrm{FCG}=$ final clinical group; $\mathrm{MNC}=$ mononuclear cells; HPF $=$ high-power field; $25-75 \mathrm{p}=2$ 25th-75th percentiles; $\mathrm{kDNA}$ $=$ kinetoplast $\mathrm{DNA} ; \mathrm{HF}=$ heart failure; $\mathrm{LV}=$ left ventricle; $\mathrm{RA}=$ right atrium; $\mathrm{RV}=$ right ventricle; $\mathrm{ND}=$ not done; $\mathrm{VS}=\mathrm{ventricular}$ septum; $\mathrm{LA}=$ left atrium.

The histologic sections were classified in three categories, those with mild fibrosis (less than $10 \%$ ), those with moderate fibrosis (between $10 \%$ and $20 \%$ ), and those with severe fibrosis (more than 20\%). ${ }^{12}$

To compare the number of MNC/HPF and the volume fraction of the fibrosis between patient groups, we analyzed one section of the left ventricular free wall region from each heart. In cases where two sections of the left ventricular free wall were previously selected, we analyzed the one with the highest degree of inflammation.

Polymerase chain reaction. Two to five $10 \mu \mathrm{m}$-thick serial tissue specimens consecutive to the section stained for histologic analysis were transferred into sterile polypropylene microtubes (Eppendorf AF, Hamburg, Germany) for isolation of DNA. To avoid cross-contamination between samples, sterile disposable instruments and gloves were used during handling. The DNA was extracted using the QiAmp tissue kit (Qiagen, Valencia, CA) following the manufacturer's recommendations for paraffin-embedded tissues, as previously reported. ${ }^{16}$ Because the tissues were obtained from archival specimens, some of them from necropsies collected more than
10 years ago, the integrity of the purified DNA was firstly verified by the amplification of a human $\beta$-globin gene fragment, as reported previously. ${ }^{17}$ Accordingly, we searched for $T$. cruzi DNA only in those samples that were found to be positive by a $\beta$-globin gene-based PCR.

A hot-start PCR procedure targeted to the 330-basepair minicircle fragment of the $T$. cruzi kinetoplast genome was performed in $50-\mu \mathrm{L}$ reactions using PCR tubes containing wax beads (Molecular BioProducts, Inc., San Diego, CA). The $12-\mu \mathrm{L}$ lower mixture carried $2 \mu \mathrm{L}$ of $25 \mathrm{mM} \mathrm{MgCl}_{2}, 5 \mu \mathrm{L}$ of $2.5 \mathrm{mM}$ of each deoxynucleotide triphosphate (Promega, Madison, WI), $1.5 \mu \mathrm{L}$ of $50 \mu \mathrm{M}$ of primers $121\left(5^{\prime}-\right.$ AAATAATGTACGGG(T/G)GAGATGCATGA-3') and 122 (5'-GGTTCGATTGGGGTT GGTGTAATATA-3'), and $1.2 \mu \mathrm{L}$ of $10 \times$ Taq buffer (Gibco-BRL, Gaithersburg, MD). The $33-\mu \mathrm{L}$ upper mixture contained $4 \mu \mathrm{L}$ of $25 \mathrm{mM}$ $\mathrm{MgCl}_{2}, 3.3 \mu \mathrm{L}$ of $10 \times$ Taq buffer, 1.25 units of Taq DNA polymerase (Gibco-BRL), and $5 \mu \mathrm{L}$ of specimen DNA. Amplification was performed in a MJR PTC-100 thermocycler (MJ Research, Inc., Waltham, MA) under the conditions previously reported. ${ }^{18}$ The PCR products were analyzed by $3 \%$ 
agarose gel electrophoresis followed by Southern hybridization, as previously reported. ${ }^{18}$ The results obtained by the kinetoplast DNA (kDNA)-PCR on the serial tissue specimens consecutive to the histologic heart section were scored as 1 if at least one of them amplified T. cruzi $\mathrm{kDNA}$ or as 0 if all the tested specimens were PCR negative (Table 2).

In addition, a nested PCR procedure targeted to the 435basepair short interspersed repetitive element (SIRE) ${ }^{19}$ of the nuclear genome of $T$. cruzi was assayed in the heart sections obtained from two group B patients (cases 9 and 12, Table 1). The first round of the SIRE PCR was carried out in a $50-\mu \mathrm{L}$ volume reaction containing $15 \mathrm{pm}$ of primers SIs (5'-GGAGAGCTGGCTAACTTAAT-3') and SIa (5'GGGGTCCTCCAACCACAAGAC-3') using the following cycling conditions: one cycle at $94^{\circ} \mathrm{C}$ for five minutes and $58^{\circ} \mathrm{C}$ for two minutes, followed by 35 cycles at $72^{\circ} \mathrm{C}$ for one minute, $94^{\circ} \mathrm{C}$ for one minute, and $58^{\circ} \mathrm{C}$ for one minute, and a final step at $72^{\circ} \mathrm{C}$ for seven minutes. The second round of SIRE PCR was carried out in a $50-\mu \mathrm{L}$ volume reaction with $15 \mathrm{pm}$ of primers SIns (5'-GTATGAATCTTTTGGGAAGAAC-3') and SIna (5'-TTACTTACGAAGTGGCAGACT-3') using the following cycling conditions: one cycle at $94^{\circ} \mathrm{C}$ for five minutes and $55^{\circ} \mathrm{C}$ for two minutes, followed by 35 cycles at $72^{\circ} \mathrm{C}$ for one minute, $94^{\circ} \mathrm{C}$ for one minute, and $55^{\circ} \mathrm{C}$ for one minute, and a final step at $72^{\circ} \mathrm{C}$ for 10 minutes. The SIRE PCR products were visualized by UV light after electrophoresis in ethidium bromide-stained 3\% agarose gels.

Negative controls for each PCR consisted of specimen preparation reagents without DNA. Positive specimen controls consisted of $10-\mu \mathrm{m}$ serial brain tissue specimens obtained from a necropsy of a patient with acquired immunodeficiency syndrome who died of chagasic meningoencephalitis. Purification of DNA from tissue specimens, assembling of reagent mixtures, cycling, gel electrophoresis, and hybridization procedures were carried out in different laboratory working areas. The PCR was carried out blinded to the clinical and/or the histologic findings.

Statistical analysis. Continuous variables were analyzed by one-way analysis of variance (ANOVA) and unpaired $t$-tests when appropriate. Categorical variables were compared by the chi-square test and Fisher's exact test. The number of inflammatory cells and the area of fibrosis in the histologic heart sections were expressed as median values. The agreement between inflammation and fibrosis was studied using the Spearman correlation coefficient. The Kruskal-Wallis one-way ANOVA was used to test the differences between groups. The Mann-Whitney $U$ test was used to evaluate the agreement between the median value of inflammatory cell counts and the median percentage of fibrosis with the PCR scores in each heart tissue block. $P$ values $<0.05$ were considered statistically significant. The pathologic and clinical data were analyzed using the SPSS ${ }^{\circledR} 6.1$ statistical analysis software for Windows (SPSS, Inc., Chicago, IL).

\section{RESULTS}

Clinical features of the study groups. Group A was composed of six cChHD patients, four males and two females, with a mean \pm SD age of $54.83 \pm 11.58$ years, without evidence of $\mathrm{HF}$ at the moment of death. The mean \pm SD time of follow-up was $864.2 \pm 981.9$ days (Table 1 ).

Group B were composed of 10 cChHD patients, five males and five females, with a mean \pm SD age of $50.60 \pm 14.37$ years, with evidence of $\mathrm{HF}$ as cause of death or indication for heart transplantation. The mean \pm SD time of follow-up was 968.6 \pm 925.8 days and the mean \pm duration of the clinical symptoms of heart failure was $17.80 \pm 9.55$ months (Table 1 ).

Group C was composed of six patients with DCM, four males and two females, with a mean \pm SD age of $47.50 \pm 13.68$ years, with $\mathrm{HF}$ at the moment of death or heart transplantation. The mean \pm SD time of follow-up was $426.67 \pm 319.2$ days and the mean \pm SD duration of the clinical symptoms of heart failure was $25.67 \pm 17.47$ months (Table 1 ). The mean ages, time of follow-up, and period with heart failure were similar among groups B and C (Table 1).

During monitoring of the cChHD patients, new electrocardiographic changes (NECs) were detected in two of six cases in group $\mathrm{A}$ and in all patients in group $\mathrm{B}(P=0.008)$. Conversely, an NEC occurred only in one of six cases in control group $\mathrm{C}$, a significant difference when compared with the NECs found in group B $(P=0.001)$. No deterioration of the clinical group was detected in group $\mathrm{A}$; however, a clinical deterioration occurred in 3 of 10 patients in group B ( $P$ not significant). The causes of death or heart transplantation for all patients are shown in Table 1 .

Histopathologic findings. The mean \pm SD heart weight was $467.5 \pm 170.0$ grams, $490.5 \pm 114.7$ grams, and $587.5 \pm 200.0$ grams in groups $\mathrm{A}, \mathrm{B}$, and $\mathrm{C}$ respectively ( $P$ not significant) (Table 2). We observed borderline myocarditis in three of 16 hearts and active myocarditis in 12 of 16 hearts from cChHD patients. In contrast, only two of six DCM hearts presented borderline myocarditis and none had active myocarditis (Table 2). The morphometric data for inflammation and fibrosis are shown in Table 2. There was a positive correlation between the inflammation and fibrosis measured in the histologic heart sections of patients with Chagas disease (Spearman correlation coefficient $=0.388, P<0.001$ ).

A comparison between the median intensity of heart tissue inflammation and the percentage of fibrosis, as measured in the left ventricular free wall sections of the hearts from groups $\mathrm{A}, \mathrm{B}$, and $\mathrm{C}$ is shown in Figure 1. The median number of $\mathrm{MNC} / \mathrm{HPF}$ in left ventricular wall specimens in group $\mathrm{A}$ $(11$, range $=11-16)$ was significantly lower than in group $\mathrm{B}$ $(31$, range $=17-53)(P=0.039)($ Figure 1A). The percentage of fibrosis in the same left ventricular wall sections was $15.5 \%$ (range $=6-18 \%)$ in group $\mathrm{A}$ and $20.5 \%$ (range $=15-30 \%$ ) in Group B ( $P$ not significant) (Figure 1B). The comparison of inflammation between sections from groups $\mathrm{B}$ and $\mathrm{C}$ showed significant differences; we observed a median value of 31 (range $=17-53$ ) $\mathrm{MNC} / \mathrm{HPF}$ in group $\mathrm{B}$ compared with 7 (range $=6-11) \mathrm{MNC} / \mathrm{HPF}$ in group $\mathrm{C}(P=0.005)$ (Figure $1 \mathrm{~A}$ ). The percentage of fibrosis in group $\mathrm{C}$ was $10.5 \%$ (range $=9-12 \%)$, which was significantly lower than that measured in group $\mathrm{B}(P=0.005)$ (Figure $1 \mathrm{~B})$. No significant differences in inflammation and fibrosis were observed between groups $\mathrm{A}$ and $\mathrm{C}$ (Figure $1 \mathrm{~A}$ and $\mathrm{B}$ ).

The intensity of inflammation and fibrosis was also evaluated in the four layers of the myocardium (Figure 1C and D). In the subepicardium, group $\mathrm{B}$ showed higher MNC/HPF counts and a higher percentage of fibrosis than groups $\mathrm{A}$ and $\mathrm{C}(P<0.001)$. In the outer mesocardium, group B specimens showed higher counts of MNC/HPF than those in groups $\mathrm{A}$ or $\mathrm{C}(P<0.001)$ and a higher percentage of fibrosis than those in groups $\mathrm{A}$ or $\mathrm{C}(P<0.001)$. In the inner mesocardium, 

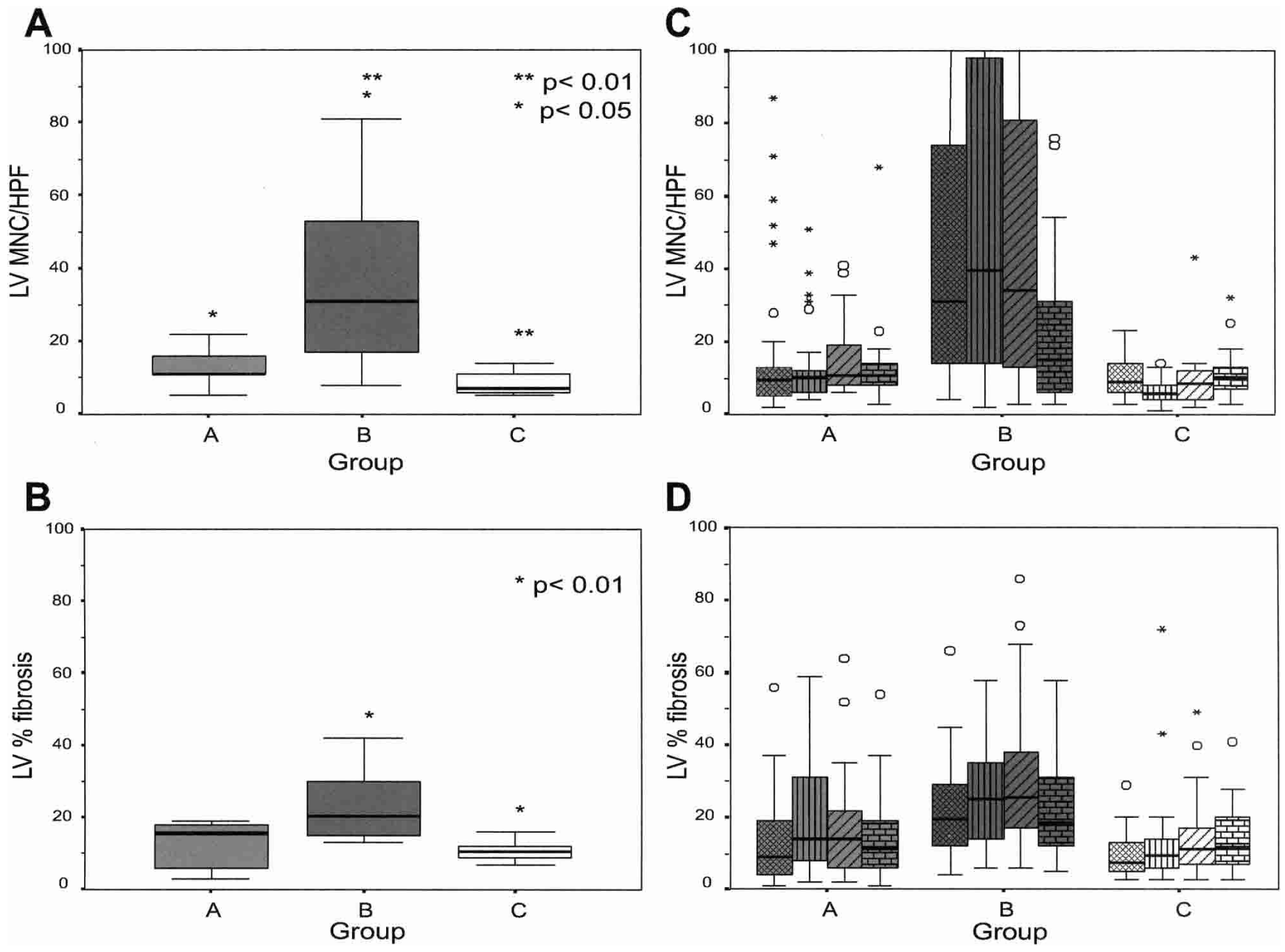

FIGURE 1. Comparison of the median number of mononuclear cells per high-power field (MNC/HPF) (A) and the volume fraction of fibrosis (B) in 20 HPFs examined at 400× magnification in left ventricle (LV) free wall sections of hearts from patients with chronic Chagas disease (groups A and B) and dilated cardiomyopathy patients (group C) stained with hematoxylin and eosin and Masson's trichrome. Median MNC/HPF (C) and percentage of fibrosis (D) were measured in five HPFs of the subepicardial myocardium (cross-hatched bars), five of the outer mesocardium (vertically striped bars), five of the inner mesocardium (diagonally striped bars), and five of the subendocardium (brick-patterned bars). Error bars show the $25 \%$ and $75 \%$ percentiles.

group B specimens showed higher counts of MNC/HPF than those in groups $\mathrm{A}$ or $\mathrm{C}(P<0.001)$ and a higher percentage of fibrosis than those in groups $\mathrm{A}(P<0.01)$ or $\mathrm{C}(P<0.001)$. Interestingly, sections from the outer and inner mesocardium of group A patients contained a higher number of MNC/HPF than group $\mathrm{C}(P<0.001$ and $P<0.01$, respectively), but there were no differences in the percentage of fibrosis. In the subendocardium, group B specimens showed slightly more inflammation than group $\mathrm{C}(P=0.045)$, but there were no differences when compared with group A ( $P$ not significant) (Figure 1C). Group B samples showed more fibrosis than those from groups $\mathrm{A}(P<0.01)$ or $\mathrm{C}(P<0.01)$, but there were no differences between groups $A$ and $C$ (Figure 1D). As shown in Figure 1D, in cChHD, the fibrosis was higher in the mesocardial layers, whereas in DCM the subendocardium was more involved.

The appearance of NECs in all patients (groups A, B, and C) correlated with inflammatory infiltration in the LV wall samples (Spearman correlation coefficient $=0.578, P<0.01$ ), as well as with the percentage of fibrosis $(\rho=0.620, P<$ $0.005)$.
Detection of $T$. cruzi DNA by PCR. We tested for the presence of T. cruzi DNA in serial tissue specimens consecutive to the section stained for morphometric analysis from each selected heart tissue block (sections a and b, Table 2). One hundred nineteen specimens were processed for PCR analysis; 82 were positive for amplification of the human $\beta$-globin gene (Table 2) and were further analyzed by the kDNA-based PCR. Parasite kDNA amplicons were obtained from $53(75.7 \%)$ of 70 tissue specimens tested (Table 2) from 15 of the 16 hearts from patients with Chagas disease analyzed in this study. The only heart sections for which no parasite DNA could be amplified were those from case 1 , a patient with positive serologic test results for Chagas disease but without clinical or histologic signs of myocarditis (Table 2 and Figure 2A and lane 1). None of the 12 heart specimens from hearts of DCM patients were positive for $T$. cruzi kDNA (Table 2).

The PCR results observed after agarose gel electrophoresis (I) and hybridization with a $T$. cruzi kinetoplast radioactive probe (II) are shown in Figure 2. Nucleic acids were obtained from preparations of tissue specimens consecutive to the 


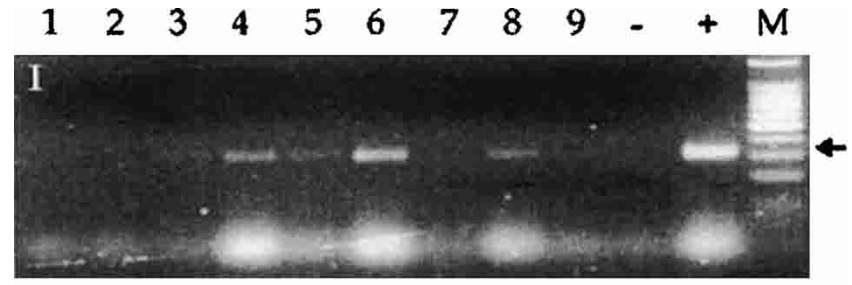

II
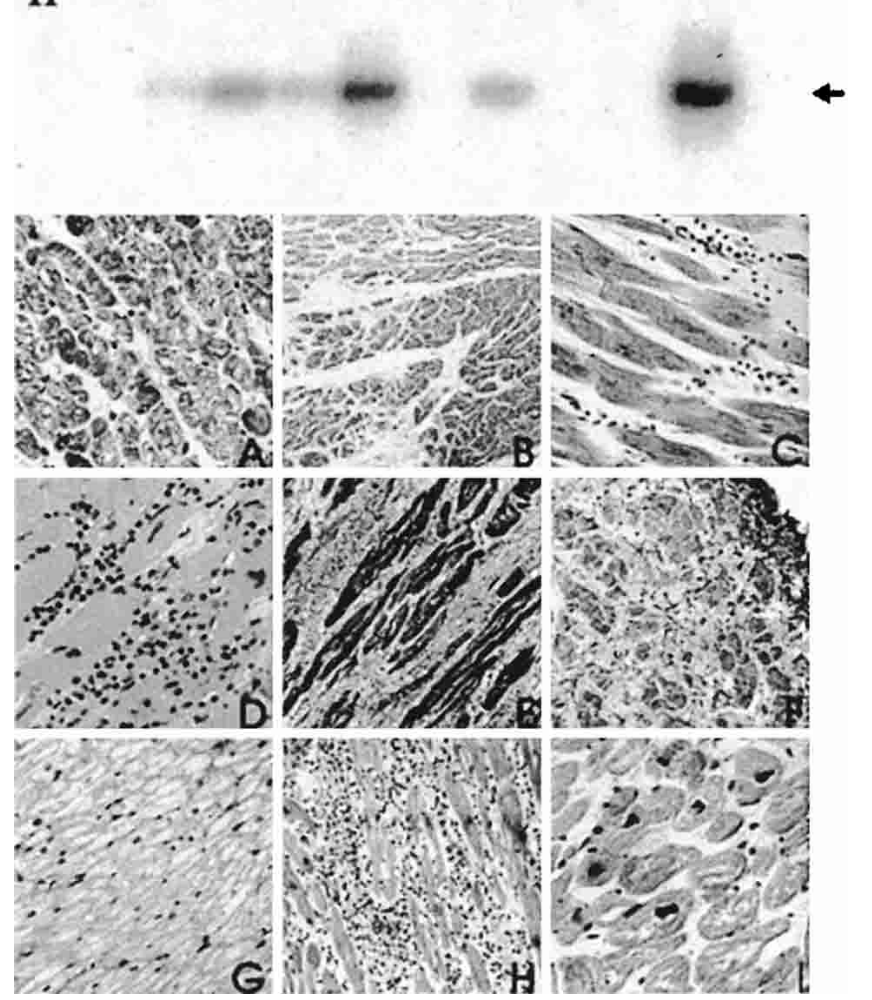

FIGURE 2. Agarose gel electrophoresis (I) and Southern hybridization (II) showing kinetoplast DNA (kDNA)-based polymerase chain reaction (PCR) results obtained by amplification of DNA from heart tissue samples. Lanes 1-9 of the gel correspond to the micrographs A-I. The arrows indicate the 330-basepair kDNA amplicon. $=$ negative $\mathrm{kDNA}$ PCR control; $+=$ positive $T$. cruzi $\mathrm{kDNA}$ PCR control, lane $\mathbf{M}=100$-basepair molecular weight marker. A-I, Microscopic examination of heart tissue sections corresponding to the ones tested by the PCR. A, Case 1a, left ventricle free wall (Masson's trichrome stained, magnification $\times 200$ ). B, Case 3a, anterolateral left ventricle (hematoxylin and eosin stained, magnification $\times 200$ ). C, Case $3 b$, lateral left ventricle, focal myocarditis (hematoxylin and eosin stained, magnification $\times 400)$. $\mathbf{D}$, Case $7 b$, posterolateral left ventricle, active, diffuse myocarditis (hematoxylin and eosin stained, magnification $\times 400$ ). $\mathbf{E}$, Case 9 b, anterolateral left ventricle, active myocarditis with severe fibrosis (Masson's trichrome stained, magnification $\times 200$ ). F, Case $14 \mathrm{~b}$, lateral left ventricle, intense pericarditis, and diffuse myocarditis (hematoxylin and eosin stained, magnification $\times 200$ ). G, Case 16a, left auricular wall (hematoxylin and eosin stained, magnification $\times 200)$. $\mathbf{H}$, Case 16 b, lateral left ventricular wall (Masson's trichrome stained, magnification $\times 200$ ). I, Dilated cardiomyopathy case $\mathrm{E}$, lateral left ventricle wall (hematoxylin and eosin stained, magnification $\times 400$ ).

stained sections shown in Figure 2. Two cases from group A are shown in Figure 2A, B, and C. Figure 2, lane 1 shows the only example in which no parasite DNA could be amplified from heart sections of case 1 (Tables 1 and 2 and Figure 2A), a patient who died in the indeterminate phase of Chagas disease, without any evidence of myocarditis. Figure 2, lanes 2 and 3 show that for patient 3 (Table 1) parasite DNA was amplified only from the tissue section with the highest degree of inflammation (Figure 2C and Table 2, histologic section $3 b$ ).

Four PCR results from patients in group $\mathrm{B}$ are shown in Figure 2D-H. Patient 7 was a 48 -year-old man admitted into clinical group I who had clinical deterioration and was reassigned to Kuschnir's group III (Table 1). The histologic analysis of the heart tissue sections from the left ventricular free wall (Figure 2D and Table 2, histologic section 7b) showed evidence of active myocarditis; parasite kDNA was obtained from all the tested serial tissue specimens (Figure 2, lane 4). Case 9 was a 54-year-old woman who was admitted into clinical group II, progressed to clinical group III, and died after a rapid onset of symptoms of HF. The histologic sections from her heart showed active myocarditis (Table 2, histologic section $9 \mathrm{~b}$ and Figure 2E) with evidence of T. cruzi kDNA (Figure 2, lane 5). Patient 14 died of heart failure at age 27 (Figure $2 \mathrm{~F})$. In the left ventricular free wall from his heart necropsy, all tested serial samples were PCR positive (Table 2, histologic sections $14 \mathrm{a}$ and $14 \mathrm{~b}$ and Figure 2, lane 6). Interestingly, amastigote nests were detected in another histologic section, adjacent to the ones analyzed by the PCR. Case 16 was a 46-year-old woman who underwent a heart transplant. Her explanted heart showed regions with very low counts of inflammatory cells (Figure 2G and $\mathrm{H}$ ); however, parasite DNA was found in specimens consecutive to the histologic section with myocarditis (Figure 2H, lane 8). In Group C, parasite kDNA was not detected in any DCM control specimen, as shown in Figure 2I, lane 9 (case $\mathrm{C}$ in Table 2). The result of the kDNA PCR was negative for DNA samples extracted from archival specimens of brain, lung, kidney, and liver collected at necropsies from cases 3, 6, 14, and 16 .

Six tissue sections positive for T. cruzi kDNA from patients $8,9,10,11,12$, and 14 were further tested for the presence of the nuclear, multicopy SIRE. ${ }^{19}$ A nested PCR procedure resulted in the amplification of a 230-basepair SIRE fragment from two heart samples (cases 9 and 12, Table 2). The amplicon from case 9 was sequenced and aligned with those from parasite strains CL-Brenner and Tulahuen II, ${ }^{19}$ as well as with SIRE sequences amplified from two endomyocardial biopsy specimens (Figure 3). ${ }^{20}$

Association of inflammation and fibrosis with $T$. cruzi DNA in heart lesions. The degree of inflammation and fibrosis in the histologic sections was associated with the detection of $T$. cruzi kDNA by PCR (Figure 4). Heart sections were classified into three categories according to the MNC counts and the percentage of fibrosis (see Materials and Methods). Accordingly, the PCR result was positive in 1) serial tissue samples derived from only one $(15 \%)$ of seven heart sections with low inflammation collected from hearts $1-4,8$, and 10 (Table 2), 2) eight (89\%) of nine sections with moderate inflammation (Figure 2, lane 4 and micrograph D from case 7), collected from hearts $2,4-7,11,12$, and 16 (Table 2), and 3) all 14 (100\%) sections with high inflammation (Figure 2, lane 3 and micrograph C; lane 6 and micrograph F), collected from hearts 3, 7, and 9-16 (Table 2) and Figure 4) $(P<0.0001)$.

The association of inflammation with detection of $T$. cruzi DNA was also observed when histologic sections with different degrees of inflammation from the same heart were compared. Accordingly, in cases 2 and 3 in group A and cases 10 and 16 in group B, parasite DNA was amplified only from 


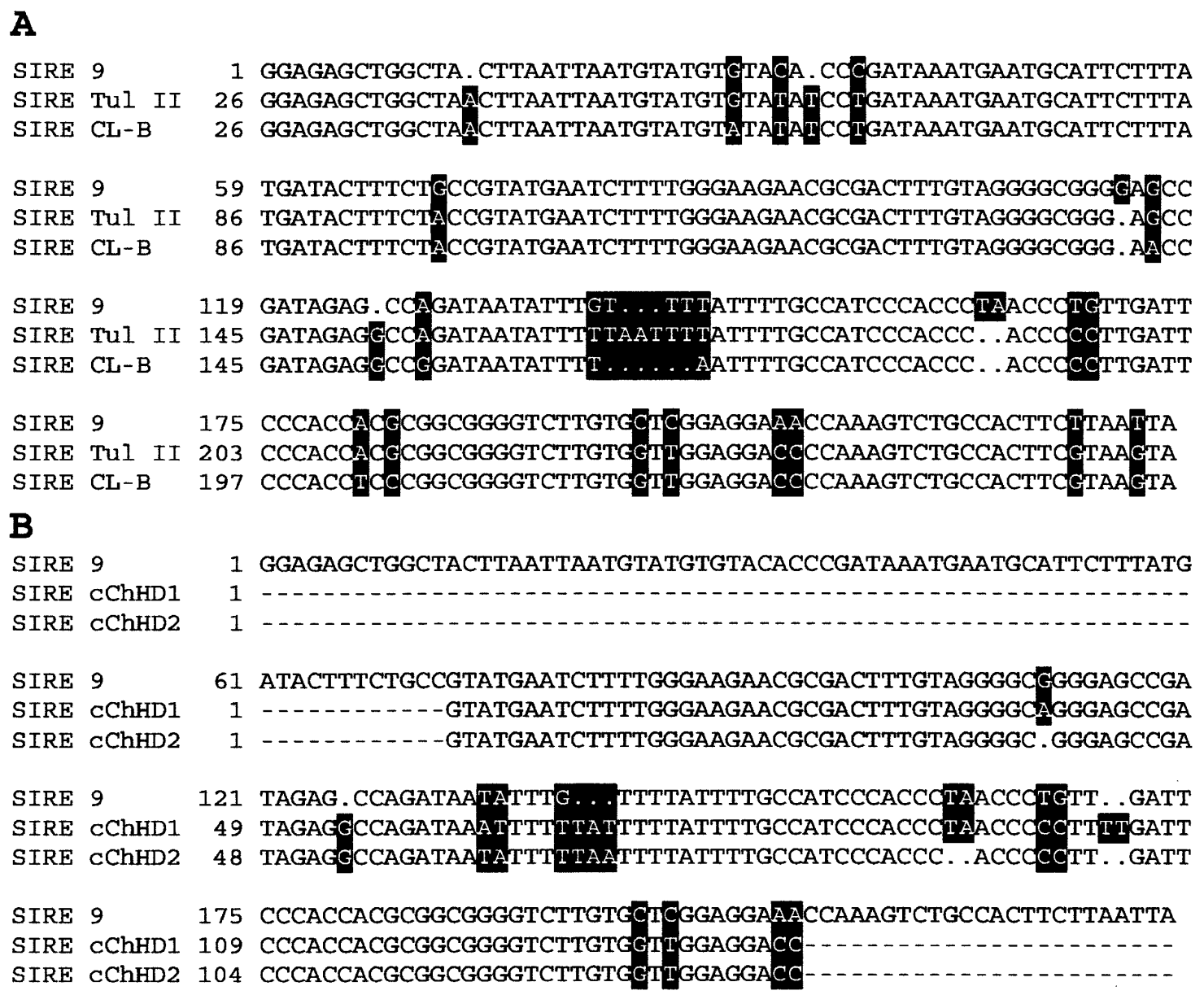

FIGURE 3. Sequence analysis of a short interspersed repetitive element (SIRE) fragment obtained by a nested polymerase chain reaction from a heart tissue section of case 9 (SIRE 9, Genbank accession number 128529). A, Comparison of SIRE 9 with SIRE sequences from Trypanosoma cruzi stock Tulahuen II (SIRE Tul II) and clone CL-Brenner (SIRE CL-B). B, Comparison of SIRE 9 with SIRE sequences obtained from endomyocardial biopsies of two chronic Chagas heart disease patients. ${ }^{20}$ White letters shaded in black show non-conserved nucleotides among aligned sequences.

those sections with the highest MNC counts (Figure 2, case 16, lane 7 and micrograph $\mathrm{G}$; lane 8 and micrograph $\mathrm{H}$ ).

Parasite DNA was also linked with the degree of fibrosis found in the same tissue sections. It was detected in serial samples from two $(33.3 \%)$ of six sections with mild fibrosis collected from hearts $1,2,5$, and 16 , in $11(78.6 \%)$ of 14 sections with moderate fibrosis collected from hearts $3-6,10,12$, 13 , and 16 , and in all 10 sections $(100 \%)$ with severe fibrosis collected from hearts 7-9, 11, 14, and 15) $(P<0.01)$ (Figure 4).

Parasite DNA and apical aneurysm. Heart sections from cardiac apexes of cases 1 and 2 of Group A (Kuschniŕs Group 0 ) as well as cases 7 and 15 from Group B (Kuschnir's Group III) were tested by kDNA based PCR. In apical samples from Group A cases there were no evidences of parasite DNA, whereas in those from Group B cases the PCR results were positive (Table 2).

Association of $T$. cruzi $\mathrm{kDNA}$ with cause of death or transplantation and disease progression. The proportion of serial tissue specimens containing T. cruzi kDNA was 45\% (10 of $22)$ in group A and $89.6 \%$ (43 of 48$)$ in group B $(P<0.001)$ (Figure 5). Furthermore, the PCR result was positive in $25 \%$ (3 of 12) of the heart specimens from Kuschnir' groups 0 and I, in $70 \%$ (7 of 10 ) of the samples from group II, and in $90 \%$
(43 of 48$)$ of the samples from Group III $(P<0.001)$ (Figure $5)$. Moreover, parasite DNA was detected in all patients who showed clinical deterioration evolving to Kuschnir's group III (Table 2).

\section{DISCUSSION}

We investigated the association between the clinical, ECG data, and heart histologic features of followed-up cChHD and DCM patients with the evidence of parasitic DNA at the sites of cardiac lesions. When histologic specimens from the hearts of cChHD and DCM patients with HF with similar mean ages, times of follow-up, and New York Heart Association classes (Tables 1 and 2) were compared, we confirmed the far more intense myocarditis and fibrosis in $\mathrm{cChHD}^{21-23}$ associated with parasitic DNA, in contrast to the scarcity of inflammation $^{24}$ and moderate predominantly subendocardial fibrosis and negative T. cruzi PCR findings in DCM patients ${ }^{25,26}$ (Figure $1 \mathrm{~A}$ and $\mathrm{B}$ ).

The inflammation in cChHD hearts with HF (group B) was higher in the subepicardium and mesocardial layers, reflecting the fact that bloodstream parasites reach the heart from 

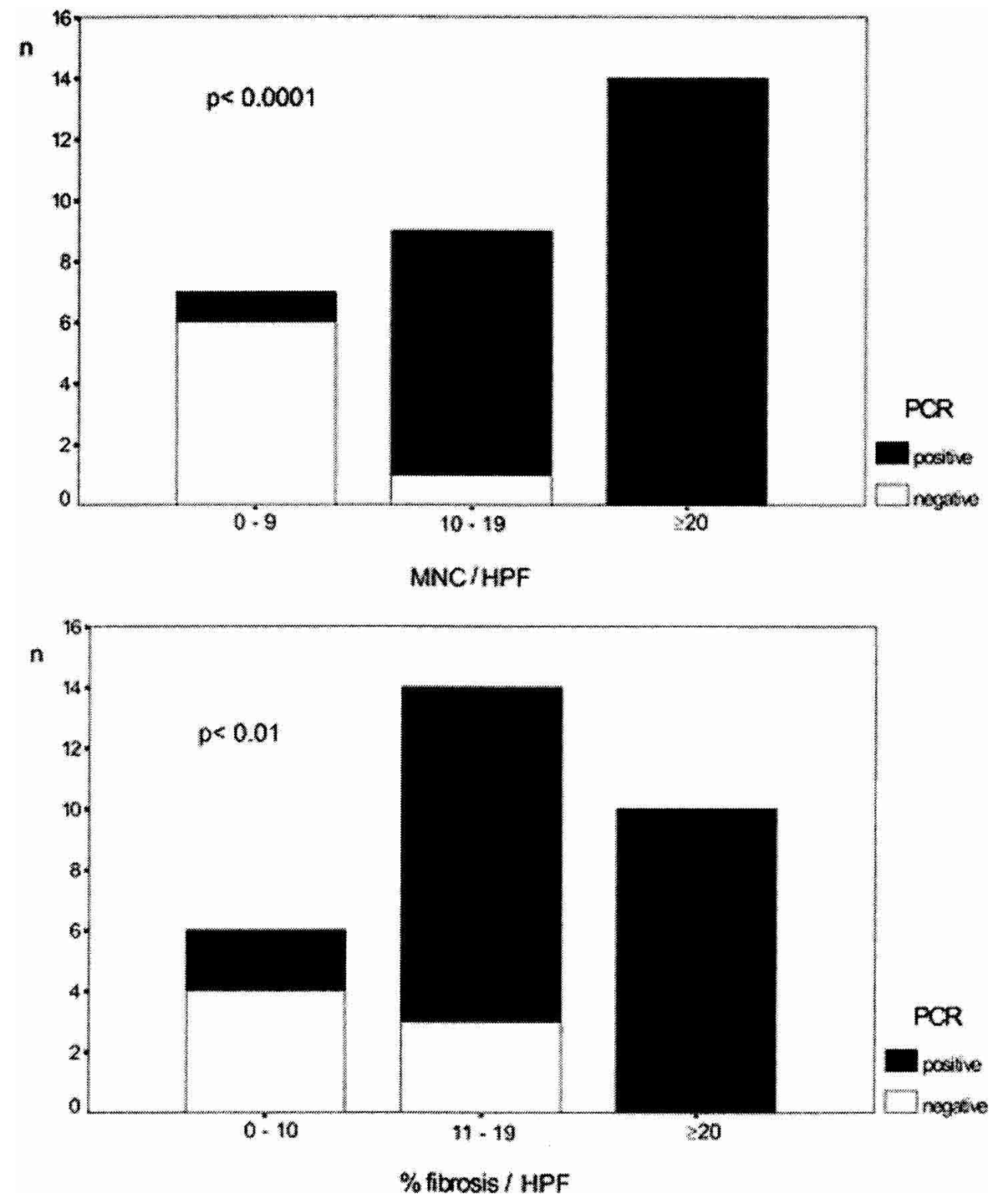

FIGURE 4. Association of Trypanosoma cruzi kinetoplast DNA-based polymerase chain reaction (PCR) results with the extent of inflammation (top) and the percentage of fibrosis (bottom). $\mathrm{n}=$ number of histologic sections tested; MNC/HPF = mononuclear cells per high-power field.

the coronary vessels, contacting the epicardium (Figure 1C). The distribution of fibrosis in the myocardial layers of cChHD with HF followed the pattern of inflammation, which was clearly not the case for DCM. Indeed, heart sections from cChHD patients showed more fibrosis in the mesocardium, whereas in DCM patients the subendocardium seemed to be more involved (Figure 1D), probably as a consequence of the disturbance of oxygen supply and demand. ${ }^{25-27}$

The appearance of NECs during follow-up is a striking characteristic of $\mathrm{cChHD} .^{2}$ The progression of ECG abnormalities was reported to be approximately $20-25 \%$ in longitudinal population studies of individuals chronically infected with $T$. cruzi for seven or more years. ${ }^{28-30}$ In this study, NECs were detected in $100 \%$ of cases in group B, in $30 \%$ of cases from group A, and in only $17 \%$ in group C. Remarkably, in group B the ECG evolution was associated with heart failure and death, with heart tissue necropsies showing diffuse and fibrosing myocarditis, which are typical signs of end-stage cChHD that all linked to the detection of parasite DNA.

The paucity of parasite nests in hearts of cChHD patients led several investigators to discard a role for the parasite in its pathogenesis. ${ }^{6,17,31}$ In certain series of necropsies, amastigote nests were identified in only $25-36 \%$ of the hearts. ${ }^{21,32,33}$ However, immunohistochemical analysis using monoclonal antibodies to $T$. cruzi allowed detection of $T$. cruzi antigens in $71 \%$ of the cardiac regions with moderate or severe myocarditis and in only $16.6 \%$ with mild or absent myocarditis. ${ }^{7}$ Moreover, a significant correlation between the presence of parasite antigens and increased CD8 T cell counts has been also reported. ${ }^{34}$

The PCR has shown the presence of nuclear and kinetoplastid sequences from the parasite in biopsy or necropsy specimens from hearts and digestive tissues of patients with 

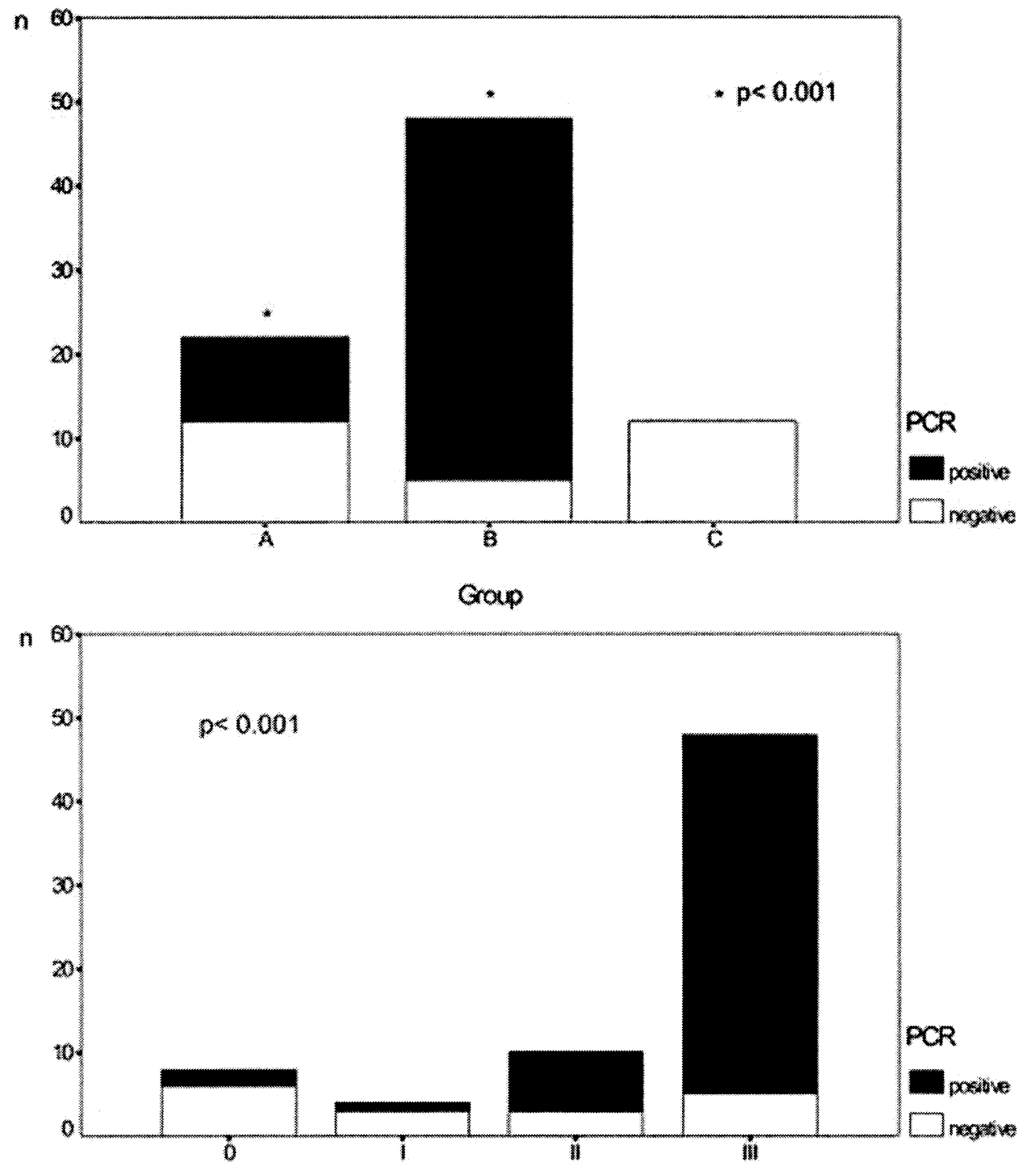

Final chagasic dinical group

Figure 5. Association of Trypanosoma cruzi kinetoplast DNA-based polymerase chain reaction (PCR) results with cause of death or heart transplantation (top) and final clinical group (bottom) in chronic Chagas heart disease. $\mathrm{n}=$ number of serial tissue samples from the histologic sections tested. 0, I, II, and III = chronic Chagas heart disease groups classified following the criteria of Kuschnir.

chronic Chagas disease from endemic regions of Brazil and Venezuela. $^{8-11}$ In the present study, amastigote nests were detected in only one heart tissue block (case 14 in group B), whereas the PCR amplified the highly repetitive kinetoplastid minicircle sequence in 15 of 16 heart necropsy specimens (Table 2). For the first time, the middle repetitive nuclear element known as SIRE $^{19}$ has been amplified from an eightyear-old heart preparation and sequenced (Figure 3). The characterization of $T$. cruzi nuclear DNA sequences from these archival necropsy specimens, as well as those from heart biopsy specimens,${ }^{20}$ provide a starting point to determine the genomic structure of the parasite populations associated with the human tissue lesions.

Our study suggests that there is a strong association between the histologic evidence of heart tissue damage and T. cruzi amplicons. Indeed, there was a significant correlation between the number of tissue sections positive by PCR and the intensity of heart inflammation, as well as fibrosis at the corresponding cardiac lesions (Figure 4). The proportion of PCR-positive sections increased in patients who died or received a heart transplant due to HF (group B) compared with those from patients who had died of other causes (group A) (Figure 5). This finding suggests that the transition from a chronic asymptomatic period of the disease, represented by infected individuals with the clinical profile of group A patients, to manifest $\mathrm{cChHD}$, the clinical profile of group B patients, is directly associated with the detection of parasite DNA in the affected tissues. Moreover, amplification of specific parasite DNA sequences was linked to clinical deterioration (Figure 5).

The absence of intact parasites at the sites of inflammation suggests that microorganisms invading the myocardium are rapidly destroyed, probably immunologically, whereas DNA 
and antigens may be still detected at the sites of injury. Based on experimental evidence showing that parasite DNA did not persist for more than two days in murine-infected tissues, ${ }^{35}$ PCR findings appear to indicate intact or recently destroyed parasites, rather than mere residual DNA.

The positive correlation between parasite DNA in tissue lesions and inflammation, fibrosis, and disease progression and severity suggests that during the chronic infection the parasite contacts the heart at different times and locations, invoking an immunologic response at these sites. As a direct consequence, parasites are lysed, the surrounding tissue is damaged, and replacement fibrosis ensues. The accumulation of these multifocal lesions, mainly in the left ventricular wall, leads to cardiac dysfunction. Moreover, heart damage may be also enhanced by the humoral immune response of the patient against intracellular parasite antigens, such as the $T$. cruzi ribosomal $\mathrm{P}$ proteins, which generates arrhythmogenic antibodies. $^{36,37}$

In conclusion, these results suggest not only a relevant role of the parasite in the pathogenesis and disease progression of cChHD, but also a need to develop novel anti-parasitic drugs, with sufficient efficacy to clear intracellular parasites, thus preventing the progression of heart disease. ${ }^{38,39}$

Received August 1, 2003. Accepted for publication October 22, 2003.

Acknowledgments: We are grateful to Dr. Rubén Laguens (Division de Anatomía Patológica, Instituto de Cardiología y Cirugía Cardiovascular, Fundación Favaloro, Buenos Aires, Argentina) and Dr. Felipe Kierszenbaum (Department of Microbiology, Michigan State University, East Lansing, MI) for their helpful comments on the manuscript, and to Sonia Lafon and Julia Ferrando for their skillful technical assistance.

Financial support: This work was supported by grants from the World Health Organization-Tropical Diseases Research projects, the Regional Technical Cooperation project RLA 6-0-26 and Coordinated Research Project of the International Atomic Energy Agency, Consejo Nacional de Ciencia y Tecnologia (PEI 107/97), the University of Buenos Aires, FONCyT BID 802/OC-AR PICT 01421 and PI CT 02030, the Alberto Roemmers and Bunge and Born Foundations, and Ramon Carrillo-Arturo Oñativia of the Secretary of Health of Argentina. The work of Matiano J. Levin was partially supported by an International Research Scholar grant from the Howard Hughes Medical Institute (Chevy Chase, MD).

Authors' addresses: Alejandro G. Schijman, Juan M. Burgos, Silvia Brandariz, and Mariano J. Levin, Vuelta de Obligado 2490, Second Floor, (CP 1428), Buenos Aires, Argentina, Telephone: 54-11-47832871, Fax: 54-11-4786-8578, E-mail: MLevin@dna.uba.ar. Carlos A. Vigliano, División Patología. Instituto de Cardiología y Cirugía Cardiovascular, Fundación Favaloro, Belgrano 1746 (CP 1093), Buenos Aires, Argentina, Telephone and fax : 54-11-4378-1315 and Departamento de Cardiología, Hospital Eva Perón, Ruta 8 y Diego Pombo, San Martín, Provincia de Buenos Aires, Buenos Aires, Argentina 005411-3781315. Rodofo J. Viotti, Bruno E. Lococo, María I. Leze, and Héctor A. Armenti, Departamento de Cardiología, Hospital Eva Perón, Ruta 8 y Diego Pombo, San Martín, Provincia de Buenos Aires, Buenos Aires, Argentina 005411-3781315.

\section{REFERENCES}

1. Moncayo A, 1999. Progress towards the interruption of transmission of Chagas disease in the southern countries. Medicina $(B$ Aires) 59 (suppl 2): 120-124.

2. Rosenbaum MB, 1964. Chagasic myocardiomyopathy. Prog Cardiovasc Dis 7: 199-225.

3. Storino R, Milei J, 1994. Evolución natural y estudios longitudinales. Storino R, Milei J, eds. Enfermedad de Chagas. Buenos Aires: Mosby Doyma Argentina, 593-604.
4. Brener Z, 1987. Pathogenesis and immunopathology of chronic Chagas' disease. Mem Inst Oswaldo Cruz 82 (suppl): 215-219.

5. Tarleton RL, Zhang L, 1999. Chagas disease etiology: autoimmunity or parasite persistence? Parasitol Today 15: 94-99.

6. Levin MJ, 1996. In chronic Chagas heart disease, don't forget the parasite. Parasitol Today 12: 415-416.

7. Bellotti G, Bocchi EA, de Moraes AV, Higuchi ML, BarberoMarcial M, Sosa E, Esteves-Filho A, Kalil R, Weiss R, Jatene A, Pileggi $\mathrm{F}$, 1996. In vivo detection of Trypanosoma cruzi antigens in hearts of patients with chronic Chagas' heart disease. Am Heart J 131: 301-307.

8. Jones EM, Colley DG, Tostes S, Reis Lopes E, Vnencak-Jones CL, McCurley TL, 1993. Amplification of a Trypanosoma cruzi DNA sequence from inflammatory lesions in human chagasic cardiomyopathy. Am J Trop Med Hyg 48: 348-357.

9. Vago AR, Andrade LO, Leite AA, d'Avila Reis D, Macedo AM, Adad SJ, Tostes S Jr, Moreira MC, Filho GB, Pena SD, 2000. Genetic characterization of Trypanosoma cruzi directly from tissues of patients with chronic Chagas disease: differential distribution of genetic types into diverse organs. Am J Pathol 156: $1805-1809$.

10. Olivares-Villagomez D, McCurley TL, Vnencak-Jones CL, Correa-Oliveira R, Colley DG, Carter CE, 1998. Polymerase chain reaction amplification of three different Trypanosoma cruzi DNA sequences from human chagasic cardiac tissue. Am J Trop Med Hyg 59: 563-570.

11. Anez N, Carrasco H, Parada H, Crisante G, Rojas A, Fuenmayor C, Gonzalez N, Percoco G, Borges R, Guevara P, Ramirez JL, 1999. Myocardial parasite persistence in chronic chagasic patients. Am J Trop Med Hyg 60: 726-732.

12. Kuschnir E, Sgammini H, Castro R, Evequoz C, Ledesma R, Brunetto J, 1985. Valoración de la función cardiáca por angiografía radioisotópica en pacientes con cardiopatía chagásica crónica. Arq Bras Cardiol 45: 249-256.

13. Edwards WD, Tajik AJ, Seward JB, 1981. Standardized nomenclature and anatomic basis for regional tomographic analysis of the heart. Mayo Clin Proc 56: 479-497.

14. Aretz HT, Billingham ME, Edwards WD, Factor SM, Fallon JT, Fenoglio JJ Jr, Olsen EG, Schoen FJ, 1987. Myocarditis. A histopathologic definition and classification. Am J Cardiovasc Pathol 1: 3-14.

15. Kunkel B, Llapp H, Kober G, Kaltenbach M, 1978. Light microscopic evaluation of myocardial biopsies. Kaltenbach M, Loogen F, Olsen, EGJ, eds. Cardiomyopathy and Myocardial Biopsy. Berlin: Springer Verlag, 62-70.

16. Schijman AG, Vigliano C, Burgos JM, Favaloro R, Perrone S, Laguens R, Levin M, 2000. Early diagnosis of recurrence of Trypanosoma cruzi infection by polymerase chain reaction after heart transplantation of a chronic Chagas' heart disease patient. J Heart Lung Transplant 19: 1114-1117.

17. Brandariz S.; Schijman A.; Vigliano C.; Arteman P., Viotti R., Armenti H.; Beldjord C, Levin MJ, 1995. Detection of Trypanosoma cruzi DNA from archival heart tissue of a chronic Chagas' disease reference case. Lancet 346: 1370-1371.

18. Schijman AG, Altcheh J, Burgos JM, Biancardi M, Bisio M, Levin M, Freilij H, 2003. Aetiological treatment of congenital Chagas' disease diagnosed and monitored by the polymerase chain reaction. J Antimicrob Chemother 52: 441-449.

19. Vazquez M, Lorenzi H, Schijman AG, Ben-Dov C, Levin MJ, 1999. Analysis of the distribution of SIRE in the nuclear genome of Trypanosoma cruzi. Gene 239: 207-216.

20. Elias F, Vigliano C, Laguens R, Levin MJ, Berek C, 2003. Analysis of the presence of Trypanosoma cruzi in the heart tissue of three patients with chronic Chagas' heart disease. Am J Trop Med Hyg 68: 242-247.

21. Andrade ZA, Andrade SG, 1999. Patologia. Brener Z, Andrade ZA, eds. Trypanosoma cruzi e Doença de Chagas. Rio de Janeiro: Guanabara Koogan, 199-248.

22. Machado CR, Camargos ER, Guerra LB, Moreira MC, 2000. Cardiac autonomic denervation in congestive heart failure: comparison of Chagas' heart disease with other dilated cardiomyopathy. Hum Pathol 31: 3-10.

23. Higuchi ML, Fukasawa S, De Brito T, Parzianello LC, Bellotti G, Ramirez JAF, 1999. Different microcirculatory and interstitial matrix patterns in idiopathic dilated cardiomyopathy and Cha- 
gas' disease: a three dimensional confocal microscopy study. Heart 82: 279-285.

24. Kühl U, Noutsias M, Seeberg B, Schultheiss H-P, 1996. Immunohistological evidence for a chronic intramyocardial inflammatory process in dilated cardiomyopathy. Heart 75: 295-300.

25. Unverferth DV, Baker PB, Swift SE, Chaffee R, Fetters JK, Uretsky BF, Thompson ME, Leier CV, 1986. Extent of myocardial fibrosis and cellular hypertrophy in dilated cardiomyopathy. Am J Cardiol 57: 816-820.

26. Beltrami CA, Finato N, Rocco M, Feruglio GA, Puricelli C, Cigola E, Sonnenblick EH, Olivetti G, Anversa P, 1995. The cellular basis of dilated cardiomyopathy in humans. J Mol Cell Cardiol 27: 291-305.

27. Raso P, Tafuri WL, 1971. Alterações do pericárdio na fase crônica da tripanossomíase humana e nas fases aguda e crónica da moléstia experimental. Rev Soc Bras Med Trop Sao Paulo 5: $135-153$.

28. Maguire JH, Hoff R, Sherlock I, Guimaraes AC, Sleigh AC, Ramos NB, Mott KE, Weller TH, 1987. Cardiac morbidity and mortality due to Chagas' disease: prospective electrocardiographic study of a Brazilian community. Circulation 75: 11401145.

29. Laranja F, Dias E, Nobrega G, Miranda A, 1956. Chagas' disease: a clinical epidemiologic and pathologic study. Circulation 14: $1035-1060$.

30. Andrade ZA, 1985. Bases morfológicas das arritmias na miocardite chagásica. Cançado JR, Chuster M, eds. Cardiopatia Chagásica. Belo Horizonte, Brazil: Fundaçao Carlos Chagas 79-90.

31. Kierszenbaum F, 1999. Chagas' disease and the autoimmunity hypothesis. Clin Microbiol Rev 12: 210-233.
32. Köberle F, 1958. Cardiopatia chagásica. O Hosp 53: 311-346.

33. Mott KE, Hagstrom JWC, 1965. The pathologic lesions of the cardiac autonomic nervous system in chronic Chagas' myocarditis. Circulation 31: 273-286.

34. Higuchi ML, Reis MM, Aiello VD, Benvenuti LA, Gutierrez PS, Bellotti G, Pileggi F, 1997. Association of an increase in CD8+ $\mathrm{T}$ cells with the presence of Trypanosoma cruzi antigens in chronic, human, chagasic myocarditis. Am J Trop Med Hyg 56: 485-489.

35. Zhang L, Tarleton RL, 1999. Parasite persistence correlates with disease severity and localization in chronic Chagas' disease. J Infect Dis 180: 480-486.

36. Masuda MO, Levin M, de Oliveira SF, dos Santos Costa PC, Bergami PL, dos Santos Almeida NA, Pedrosa RC, Ferrari I, Hoebeke J, Campos de Carvalho AC. 1998. Functionally active cardiac antibodies in chronic Chagas' disease are specifically blocked by Trypanosoma cruzi antigens. FASEB J 12: 15511558.

37. Chiale PA, Ferrari I, Mahler E, Vallazza MA, Elizari MV, Rosenbaum MB, Levin MJ, 2001. Differential profile and biochemical effects of antiautonomic membrane receptro antibodies in ventricular arrhythmias and sinus node dysfunction. Circulation 103: 1765-1771.

38. Viotti R, Vigliano C, Armenti H, Segura E, 1994. Treatment of chronic Chagas' disease with benznidazole: clinical and serologic evolution of patients with long-term follow-up. Am Heart J 127: $151-162$.

39. Urbina JA, 2001. Specific treatment of Chagas disease: current status and new developments. Curr Opin Infect Dis 14: 733741. 